\title{
Problematika Penerapan Pembiayaan Dengan Akad Mudhârabah Di Perbankan Syari'ah (Studi Kasus Di BRI Syari'ah Kuamang Kuning)
}

\author{
Ujang Ruhyat Syamsoni1 \\ Institut Agama Islam (IAI) Yasni Bungo \\ Email: ujangruhyatsyamsoni@iaiyasnibungo.ac.id
}

\begin{abstract}
Syari'ah bank as new financial institution that emerge latter than conventional banks within it operational will face various problematical and also own challenges for Islam bank. Therefore, whether syari'ah bank already consistent to bring nearer to both Islam banking theory with it practice.This study aims to determine the problems faced by BRI Syari'ah Kuamang Kuning in implementing the mudharabah contract in financing. This study uses a qualitative research method with an analytic descriptive approach. The research subject is BRI Syari'ah Kuamang Kuning, while the object of research is the problem of implementing the mudharabah contract on financing. the results of this research indicate that problems faced by Bank BRI Syari'ah Kuamang Kuning to applied mudharabah agreement was found alteration such definition profit dividing which depending on difficulty and mudharib need. Mudharabah agreement settlement within detailed syari'ah banking system therefore syari'ah bank could avoiding of risk when fraud occurred which carried out by mudharib party or when claim occurred from shahib almal.
\end{abstract}

Keywords: Problematic, Mudharabah Contract, And Syari'ah Banking

\begin{abstract}
Abstrak
Bank syari'ah sebagai lembaga keuangan baru yang muncul lebih belakangan dari pada bankbank konvensional di dalam operasionalnya akan menghadapi berbagai problematika yang juga merupakan tantangan tersendiri bagi bank Islam. Dengan demikian, apakah bank-bank syari'ah telah konsisten dalam mendekatkan teori-teori perbankan Islam dengan prakteknya.Penelitian ini bertujuan untuk mengetahui problem yang dihadapi oleh BRI Syari'ah Kuamang Kuning dalam menerapkan akad mudharabah dalam pembiayaan.Penelitian ini menggunakan metode penelitian kualitatif dengan pendekatan deskriftif analitik.Subjek penelitiannya BRI Syari'ah Kuamang Kuning, adapun objek penelitiannya adalah problem penerapapan akad mudharabah pada pembiayaan.Hasil penelitian menunjukkan bahwa problem yang dihadapi oleh Bank BRI Syariah Kuamang Kuning dalam mengaplikasikan akad mudharabah adalah dijumpainya pergeseran-pergeseran seperti penentuan bagi hasil yang tidak bergantung pada kesulitan dan kebutuhan mudharib. Penyelesaian akad mudharabah dalam sistem perbankan syari'ah ditentukan dalam akad yang dipersiapkan oleh bank syari'ah dengan klasula secara rinci dan detail sehingga bank syari'ah bisa menghindar dari resiko jika terjadi wanprestasi yang dilakukan oleh pihak mudharib atau jika terjadi klaim dari shahib al-mal.
\end{abstract}

Kata Kunci: Problematika, Akad Mudharabah, Dan Perbankan Syari'ah

${ }^{1}$ Dosen tetap pada Fakultas Ekonomi Dan Bisnis Islam IAI yasni Bungo 
Ujang Ruhyat Syamsoni :Problematika Penerapan Pembiayaan...

\section{A. Pendahuluan}

Secara istilah para ulama mengartikan Mudhârabah dengan redaksi yang berbeda, akan tetapi substansinya sama, yaitu suatu bentuk kerja sama antara pemilik modal (shâhibul mâl) dan pengelola modal (mudhârib) dengan pembagian keuntungan yang disepakati bersama.Mudhârabah adalah penyerahan harta dari pemilik modal/harta kepada pihak pengelola untuk diniagakan, keuntungan dibagi bersama sesuai dengan kesepakatan yang telah disepakati, sedangkan kerugian ditanggung oleh pemilik modal. Pengelola tidak menanggung kerugian material karena dia telah menanggung kerugian lain berupa tenaga dan waktu. ${ }^{2}$

Dari segi konsepnya, Mudhârabah adalah salah satu bentuk kerja sama yang mengandung manfaat dalam meningkatkan kesejahteraan ekonomi masyarakat. Di dalam akad ini, bukan saja mengandung makna ta'awun, saling membantu memenuhi kebutuhan masing-masing pihak, dan saling menutupi kekurangan masing-masing pihak. Hal ini senada dengan firman Allah Swt dalam al-Qur'an Surat al-Maidah ayat 2:

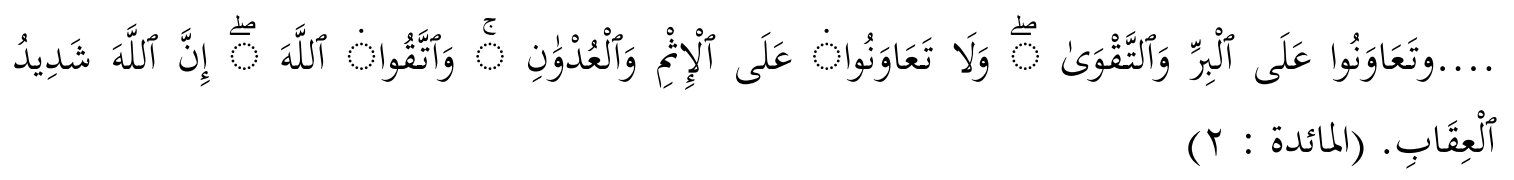

Artinya: “.....Dan tolong-menolonglah kamu dalam (mengerjakan) kebajikan dan takwa, dan jangan tolong-menolong dalam berbuat dosa dan pelanggaran. Dan bertakwalah kamu kepada Allah, sesungguhnya Allah amat berat siksaNya."3

Dalam akad mudhârabah penentuan nisbah bagi hasil dari keuntungan usaha yang disepakati bersama antara pemilik modal dan pengelola modal akan menghasilkan keseimbangan/keadilan dalam perolehan keuntungan. Demikian pula pembagian risiko berupa risiko finansial untuk shahibul mal dan risiko kehilangan waktu, tenaga dan pikiran bagi mudhâribketika usahanya mengalami kerugian adalah seimbang/adil sesuai dengan prestasi yang diberikan masingmasing pihak dalam akad mudhârabah tersebut.Hal ini berbeda dengan sistem bunga dalam akad pinjaman/kredit di bank konvensional. Pihak kreditor berada

2Neneng Nurhasanah Mudharabah dalam Teori dan Praktik, (Bandung: Refika Aditama, 2015), cet. Ke-1, h. 67.

${ }^{3}$ Kementerian Agama RI, Alqur'an dan Terjemahnya (Bandung: Syamil Qur'an, 2012), h. 106. 
Ujang Ruhyat Syamsoni :Problematika Penerapan Pembiayaan...

dalam posisi tidak seimbang dibandingkan dengan pihak debitor.Bunga harus tetap dibayarkan walaupun kegiatan usaha kreditor mengalami kerugian. ${ }^{4}$

Pada saat sekarang, mudhârabah dalam praktiknya tidak hanya dilakukan antar-individu, namun sudah melibatkan lembaga keuangan sebagai pihak yang berfungsi sebagai mediator.Hal ini memungkinkan aktivitas kerjama Mudhârabah mengalami jangkauan usaha ataupun wilayah yang semakin luas dan jumlah modal yang semakin besar. Lembaga Keuangan Syariah (LKS) seperti perbankan sebagai lembaga intermediary dapat menghimpun dana-dana dari pihak yang memiliki kemampuan finansial untuk kemudian disalurkan kepada pihak-pihak yang memiliki kemampuan dalam bidang usaha tertentu, tetapi tidak memiliki kemampuan financial untuk bekerja sama dan berbagi risiko dalam memperoleh keuntungan. ${ }^{5}$

Dengan adanya bantuan pembiayaan tersebut diharapkan mampu memacu masyarakat untuk bisa menciptakan usaha dan mampu mengembangkannya.Dalam kenyataannya masyarakat masih sulit mengembangkan usaha karena faktor permodalan.Pembiayaan yang diberikan oleh perbankkan syariah akhir-akhir ini mulai gencar di sosialisasikan untuk membangun ekonomi masyarakat.

Permodalan Mudhârabah dianggap sesuai dengan masyarakat yang akan memulai ataupun memgembangkan kegiatan usaha masyarakat. Penggunaan prinsip bagi hasil pada Mudhârabah tidak akan memberatkan pengusaha. Tidak hanya itu pembiayaan yang dilakukan oleh bank syariah menuntut kejujuran dari kedua pihak, hal ini tentu akan menciptakan kenyamanan dalam menjalin kerjasama. Menurut Muhammad,Bank syariah memiliki sifat sebagai bank berdasarkan prinsip syariah wajib memposisikan diri sebagai uswatun hasanah dalam implementasi moral dan etika bisnis yang benar atau melaksanakan etika dan moral agama dalam aktivitas ekonomi. Terlebih lagi pembiayaan ini sesuai dengan umat Islam, karena bagi hasil ini tidak mengandung riba. ${ }^{6}$

Namun sejauh ini pengelolaan pembiayaan Mudhârabah masih belum banyak dikembangkan oleh bank-bank syariah.Dalam Bank Syariah penggunanaan pembiayaan berprinsip Mudhârabah juga masih kalah dengan pembiayaan Murabahah.Pembiayaan Mudhârabah tidak bisa dihindarkan dengan resiko

\footnotetext{
${ }^{4}$ Neneng Nurhasanah, Mudharabah..., h. 227.

IIbid., h. 227-228.

6Ibid.,h. 17.
} 
Ujang Ruhyat Syamsoni :Problematika Penerapan Pembiayaan...

ketidakpastian. Hal ini karena Mudhârabah menggunakan prinsip bagi hasil atau bagi keuntungan, yang mana keuntungan yang didapatkan oleh nasabah atau pengusaha tidak selalu sama tiap bulannya. Resiko ini menjadi alasan bank-bank syariah jarang menggunakan produk ini dalam penyaluran pembiayaannya. ${ }^{7}$

Data OJK (Otoritas Jasa Keuangan) menunjukkan sebagian besar perbankan syari'ah memiliki masalah pada akad pembiayaan mudhârabah.Untuk lebih jelasnya di sajikan pada tabel 1.1 di bawah ini.

Tabel 1.1

Perbandingan pembiayaan mudhârabah, musyarakah dan murabahah dalam miliar rupiah (billion IDR) bulan Januari s/d April Tahun $2020^{8}$

\begin{tabular}{|l|c|c|c|c|}
\hline \multirow{2}{*}{ Indikator } & \multicolumn{4}{|c|}{ Tahun 2020 } \\
\cline { 2 - 5 } & Januari & Februari & Maret & April \\
\hline Mudhârabah & 8.058 & 8.085 & 8.847 & 8.163 \\
\hline Musyarakah & 73.785 & 74.769 & 76.129 & 76.704 \\
\hline Murabahah & 37.689 & 37.838 & 37.874 & 37.572 \\
\hline
\end{tabular}

Dari tabel di atas, terlihat bahwa secara umum skim pembiayaan mudhârabah dari bulan Januari 2020 sampai dengan bulan April 2020 pertumbuhannya sangat lambat dan masih dibawah angka 20 Miliar. Bahkan hampir di seluruh Indonesia penggunaan skim mudhârabahdi perbankan syari'ah masih rendah jika dibandingkan dengan pembiayaan menggunakan skim musyarakah dan murabahah.

Salah satu lembaga keuangan syariah adalah BRI Syari'ah Kuamang Kuning. Secara geografis BRI Syari'ah memiliki peluang yaitu dengan market sharenya petani perkebunan kelapa sawit dan para pedagang yang secara finansial membutuhkan banyak dana.Berdasarkan Data yang diambil dari laporan keuangan Bank BRI Syari'ah KCP Kuamang Kuning yang menunjukkan bahwa pembiayaan Mudhârabah masih jauh dibawah pembiayaan Murabahah.Laporan Kuangan Bank BRI Syariah KCP Kuamang Kuning pada tahun 2018 dan 2019. Dari laporan tersebut diperoleh data Murabahah 2018: Rp. 15.842.632.437, Tahun 2019: Rp. 10.842.165.967. Pembiayaan Mudhârabah pada tahun 2018: Rp. 967.963.041, tahun 2019: Rp. 681.068.128.

${ }^{7}$ Kasmir, Manajemen Perbankan (Jakarta: Raja Grafindo Persada, 2015), ed. Revisi, h. 101.

${ }^{8}$ Otoritas Jasa Keuangan (OJK), Statistik Perbankan Syari'ah 2016, (Jakarta: OJK, 2020), h. 27. 
Ujang Ruhyat Syamsoni :Problematika Penerapan Pembiayaan...

Berdasarkan data diatas penulis melihat kurangnya minat bank syariah ataupun masyarakat terhadap pembiayaan Mudhârabah.

\section{B. Landasan Teori}

Mudhârabah berasal dari kata dharb, berarti memukul atau berjalan. ${ }^{9}$ Ulama hizaz mengartikan Mudhârabahdengan muqaradhah sedangkan ulama irak menggunakan kata Mudhârabah.10Pengertian memukul atau berjalan ini lebih tepatnya adalah proses seorang memukulkan kakinya dalam menjalankan usaha. Hendi Suhendi mengatakan bahwa Mudhârabah adalah akad antara pemilik modal dengan pengelola modal tersebut, dengan syarat bahwa keuntungan diperoleh dua belah pihak sesuai jumlah persentase yang disepakati oleh kedua belah pihak. ${ }^{11}$

Sementara Karim menjelaskan akad Mudhârabah adalah persetujuan kerjasama antara harta dari salah satu pihak dengan kerja dari salah satu pihak. ${ }^{12}$ Karim juga menjelaskan Mudhârabah adalah bentuk kerjasama antara pihak pemilik modal (shahib al-maal) yang mempercayakan sejumlah modal kepada pengelola (mudhârib) dengan perjanjian pembagian keuntungan. Dari pengertian tersebut dapat di artikan bahwa Mudhârabah adalah suatu bentuk kerja sama yang dijalankan oleh dua pihak yang mana satu pihak sebagai pemilik modal (100\%) sedang satu pihak bertindak sebagai pelaksana usaha. ${ }^{13}$

Azfalurrahman menyebut Mudhârabah sebagai bentuk kemitraan terbatas dan mengartikannya sebagai suatu kontrak kemitraan (partnership) yang berlandaskan pada prinsip pembagian hasil dengan cara seseorang memberikan modalnya kepada orang lain untuk melakukan bisnis dan kedua belah pihak membagi keuntungan atau memikul beban kerugian berdasarkan isi perjanjian bersama. ${ }^{14}$ Dengan kata lain, Mudhârabah merupakan kemitraan antara pemilik modal dan pengelola modal yang memiliki kemampuan usaha dan mengelola dengan pembagian keuntungan ditetapkan sesuai dengan persentase yang mereka sepakati, sedangkan seluruh kerugian ditanggung oleh pemilik modal. Pengelola

${ }^{9}$ Muhamamd Syafi'i Antonio, Bank Syariah dari Teori ke Praktik (JakartaL Gema Insani Press, 2002), h. 95. Ke-4, h. 168 .

${ }^{10}$ Shalah ash-Shawi dan Abdullah al-Muslih, Fikih Ekonomi Islam,(Jakarta: Darul Haq, 2013), cet.

${ }^{11}$ Hendi Suhendi, Fiqh Muamalah (Jakarta: Raja Grafindo Persada, 2013), cet-8, h. 135.

${ }^{12}$ Adiwarman Karim, Bank Islam analisis Fiqh dan Keuangan (Jakarta: Raja grafindo Persada, 2004), h. 205.

13Ibid., hal. 103.

${ }^{14}$ Neneng Nurhasanah, Mudharabah....,h. 69. 
Ujang Ruhyat Syamsoni :Problematika Penerapan Pembiayaan...

modal tidak dikenakan beban atas kerugian karena kerugian karena kerugiannya adalah kehilangan keuntungan atas jasa yang telah dia lakukan berupa upah yang seharusnya ia terima. ${ }^{15}$

Aplikasi prinsip Mudhârabah di bagi menjadi dua yaitu MudhârabahMutlaqah dan MudhârabahMuqayyadah.Menurut Antonio MudhârabahMuthlaqah adalah bentuk kerjasama antara shahibul maal dan mudhârib yang tidak dibatasi oleh spesifikasi jenis usaha, waktu, dan daerah bisnis. Sedang MudhârabahMuqayyadah adalah kerja sama yang mana si Mudhârib dibatasi jenis usaha, waktu dan tempat usaha. ${ }^{16}$

Dalam Mudhârabah kedua belah pihak yang mengadakan perjanjian-pemilik dana dan pengelola dana- akan menentukan kapasitas baik sebagai nasabah maupun sebagai pemilik. Di dalam akad yang tercantum kata penawaran dan penerimaan merupakan pernyataan yang harus dilakukan oleh kedua belah pihak yang mengadakan kontrak dengan ketentuan di dalam perjanjian tersebut harus dinyatakan secara tersurat maupun tersirat mengenai tujuan kontrak, penawaran dan penerimaan harus disepakati oleh kedua belah pihak sesuai dalam kontrak. ${ }^{17}$

Pada bank syariah prinsip Mudhârabah diterapkan pada produk pembiayaan dan pendanaan. Dalam produk pendanaan, nasabah akan mendapatkan bagi hasil dari pendapatan bank. Sementara bagi hasil dari pembiayaan menjadi keuntungan bank sesuai dengan kerjasama yang telah disepakati di awal akad.

Aplikasi akad Mudhârabah yang ada di perbankan syari'ah berdasarkan kepada Fatwa Dewan Syariah Nasional (DSN) Nomor 07/DSN-MUI/IV/2000. Secara umum keputusan fatwa DSN-MUI tentang pembiayaan Mudhârabah dapat dibedakan menjadi tiga: pertama, ketentuan mengenai pembiayaan; kedua, ketentuan mengenai rukun dan syarat pembiayaan; dan ketiga, ketentuan mengenai hukum pembiayaan.

Muhammad menjelaskan pada posisi penghimpunan dana Mudhârabah diterapkan pada :

a. Tabungan berjangka, yaitu tabungan yang dimaksudkan untuk tujuan khusus, seperti tabungan haji, tabungan kurban, dan sebagainya.

\footnotetext{
15 Ibid

16Muhamamd Syafi'i Antonio, Bank Syari'ah....., h. 97.

${ }^{17}$ Wiroso, Produk Perbankan Syari'ah, Jakarta: LPFE, 2009), h. 331.
} 
Ujang Ruhyat Syamsoni :Problematika Penerapan Pembiayaan...

b. Deposito spesial (special investment), dimana dana yang dititipkan nasabah khusus untuk bisnis tertentu. ${ }^{18}$

Adapun pada sisi pembiayaan, Mudhârabah diterapkan untuk :

a. Pembiayaan modal kerja, seperti modal kerja perdagangan dan jasa;

b. Investasi khusus, disebut juga MudhârabahMuqayyadah, dimana sumber dana khusus dengan penyaluran yang khusus dengan syarat-syarat yang telah ditetapkan oleh shahibul mal.

Ketentuan mengenai hukum pembiayaan dalam Mudhârabah adalah: ${ }^{19}$

1. Mudhârabahboleh dibatasi pada periode tertentu;

2. Kontrak tidak boleh dikaitkan dengan sebuah kejadian di masa depan yang belum tentu terjadi.

3. Tidak ada ganti rugi dalam Mudhârabah, karena akad ini bersifat amanah, kecuali akibat dari kesalahan, kelalaian, atau pelanggaran kesepakatan; dan

4. Jika salah satu pihak tidak menunaikan kewajibannya atau terjadi perselisihan diantara kedua belah pihak, penyelesaiannya dilakukan melalui Badan Arbitrasi Syari'ah setelah tidak tercapai kesepakatan melalui musyawarah.

Tujuan akad Mudhârabah digunakan oleh bank untuk memfasilitasi pemenuhan kebutuhan permodalan bagi nasabah yang memiliki keahlian dan keterampilan guna menjalankan usaha atau proyek dengan cara melakukan investasi bagi usaha atau proyek yang bersangkutan. ${ }^{20}$

Secara teknis, dalam akad perjanjian harus disebutkan dengan jelas, baik secara tersirat maupun tersurat mengenai tujuan dari kontrak.Modal hanya diberikan untuk tujuan usaha yang sudah jelas dan disepakati bersama.Modal harus berupa uang tunai, jelas jenis mata uangnya, dan jelas jumlahnya.Modal diserahkan kepada mudhârib seluruhnya (100\%).Jika modal diserahkan secara bertahap, tahapannya harus jelas dan disepakati bersama.Biaya-biaya yang dikeluarkan untuk biaya studi kelayakan (feasibility study) atau sejenisnya tidak termasuk dalam bagian modal.Pembayaran biaya-biaya tersebut ditetapkan berdasarkan kesepakatan kedua belah pihak. ${ }^{21}$

\footnotetext{
${ }^{18}$ Muhammad Ridwan, Kontruksi Bank Syariah Indonesia (Yogyakarta: Pustaka SM, 2007), h. 97.

${ }^{19}$ Jaih Mubarok, Perkembangan Fatwa Ekonomi Syari'ah di Indonesia (Bandung: Pustaka Bani Quraisy, 2004), h. 75.

${ }^{20}$ Herry Sutanto dan Khaerul Umam, Manajemen Pemasaran Bank Syari'ah (Bandung: Pustaka Setia, 2013), h. 213.

21 Ibid., h. 214
} 
Ujang Ruhyat Syamsoni :Problematika Penerapan Pembiayaan...

Keuntungan yang diperoleh merupakan hasil dari pengelolaan dana pembiayaan Mudhârabah yang diberikan. Besar keuntungan dinyatakan dalam bentuk nisbah yang disepakati.Mudhâribharus membayar bagian keuntungan yang menjadi hak bank secara berkala sesuai dengan periode yang disepakati. Bank tidak akan menerima pembagian keuntungan, bila terjadi kegagalan atau wanprestasi yang terjadi bukan karena kelalaian mudhârib. Bila terjadi kegagalan usaha yang mengakibatkan kerugian yang disebabkan oleh kelalaian mudhârib, kerugian tersebut harus ditanggung oleh mudhârib (menjadi piutang bank). ${ }^{22}$

Jangka waktu Mudhârabahakan diatur dalam ketentuan tersendiri. Pekerja/usaha bank berhak melakukan pengawasan, tetapi tidak berhak mencampuri pekerjaan/usaha mudhârib. Bank sebagai penyedia dana tidak boleh membatasi usaha/tindakan mudhârib dalam menjalankan usahanya, kecuali sebatas perjanjian (usaha yang telah ditetapkan), atau yang menyimpang dari aturan syari'ah. ${ }^{23}$

\section{Metode Penelitian}

\section{Pendekatan Penelitian}

Penulis menggunakan penelitian kualitatif karena mempunyai tiga alasan yaitu: pertama, lebih mudah mengadakan penyesuaian dengan kenyataaan yang berdimensi ganda. Kedua, lebih mudah menyajikan secara langsung hakikat hubungan antara peneliti dan subjek penelitian.Ketiga, memiliki kepekaan dan daya penyesuaian diri dengan banyak pengaruh yang timbul dari pola-pola nilai yang dihadapi.

2. Subjek dan Objek Penelitian

Subjek dalam penelitian ini adalah BRI Syari'ah Kuamang Kuning, sedangkan objek yang menjadi sasaran penelitian adalah problematika penerapan pembiayaan dengan dengan menggunakan akad mudhârabah di BRI Syariah Kuamang Kuning.

3. Teknik Pengumpulan Data

Ada tiga teknik pengumpulan data yaitu observasi, wawancara, dan kepustakaan. 
Ujang Ruhyat Syamsoni :Problematika Penerapan Pembiayaan...

4. Teknik Analisis Data

Proses analisis data yang dilakukan oleh peneliti adalah dengan langkahlangkah: Reduksi data, Display data, Verifikasi dan Triangulasi.

\section{Pembahasan}

Untuk mengawali pembahasan ini akan menganalisa problem mudhârabah dalam perbankan syari'ah dalam hal ini mengenai pembiayaan dapat dianalisis dari dua sisi yakni dari sisi teoritis dan praktisnya. Kedua pembahasan tersebut berpijak pada aspek ektenal bank dan internal bank. Aspek ekstenal bank ini meliputi; hakekat definisi dari mudhârabah, institusionalisasi mudhârabah dan problem kejujuran.Sedangkan aspek internal bank meliputi; mekanisme penentuan bagihasil, pengaturan usaha, permasalahan.garansi dan penetapan jangka waktu kontrak.

1. Aspek Eksternal

a. Hakikat Akad Mudhârabah

Istilah mudhârabah sesungguhnya tidak muncul pada masa Nabi SAW, tetapi sebelum Nabi lahir pun sudah ada. Menurut Abraham L.Udovitch, istilah itu muncul sebagai kerjasama bangsa semennanjung Arab yang berkembang dalam konteks perdagangan para kafilah Arab sebelum Islam. Istilah itu berkembang luas ketika dalam sejarah bangsa ini berhasil menaklukkan beberapa wilayah seperti negara-negara yang termasuk dalam wilayah Timur Dekat, Afrika Utara dan sampai pada Eropa Selatan. ${ }^{24}$ Keluasan wilayah bagi perkembangan istilah mudhârabah ini membuat setiap bangsa menyebutkan dengan yang berbeda.Masyarakat Iraq, misalnya, menyebutnya dengan mudhârabah atau kadang-kadang muamalah, masayarakat Hijaz, meliputi Madinah, Mekah dan kota-kota di sekelilingnya menyebutnya dengan qiradh atau muqaradhah. ${ }^{25}$ Sedangkan masyarakat Eropa menyebutnya dengan commenda. ${ }^{26}$

Mengamati bahwa mudhârabah (muâmalah, qiradh, muqâradhah atau commenda) tidak ditemukan asal usulnya dan telah dipraktekkan secara turun-temurun dengan ketidak jelasan titik awal historisnya, ini berarti

${ }^{24}$ Abaraham L.Udovitch, Partnership abd Profit in Medival Islam (New Jersey: Princeton University Press, 1970), h.172

${ }^{25}$ Al-Kasanai, Bada'i' al-Shana'i' fi Tartibi al-Syara'i' (Beirut: Dar el-Kutub, t.th), h. 121

${ }^{26}$ Ibid, h. 174-175 
Ujang Ruhyat Syamsoni :Problematika Penerapan Pembiayaan...

membuka peluang besar untuk memberikan istilah baru bagi wialayah manapun yang mengguanakan sistem ini.Dengan demikian sistem kerjasama model mudhârabah ini perlu dianalisa lewat pengertian yang digunakannya. Para Fuqaha dan sebagian para sejarawan muslim secara umum mendefinisikan mudhârabah sebagai kerjasama antar dua pihak di mana pihak pertama memberikan fasilitas modal dam pihak kedua memberikan tenaga atau kerja. Perhitungan labanya akan dibagi dua perhitungan kerugiannya ditanggung sepenuhnya oleh pemilik modal. Dari definisi ini kiranya dapat disimpulkan bahwa kerjasama model mudhârabah ini muncul ketika terdapat dalam sebuah masyarakat yang mempunyai keinginan untuk bekerjasama antar anggotanya dalam rangka meningkatkan taraf hidup ekonominya.

b. Institusionalisasi Mudhârabah

Definisi umum mudhârabah secara fiqh disebutkan sebagai kontrak khusus antara pemilik modal dan pengusaha dalam rangka mengembangkan usaha yang mana modal berasal dari pihak pertama dan kerja dari pihak kedua, mereka bersatu dalam keuntungan dengan pembagian berdasarkan prosentase.Jika proyek (usaha) mendatangkan keuntungan maka laba dibagi berdua berdasarkan kesepakatan yang terjalin antara keduanya, jika modal tidak mempunyai kelebihan atau kekurangan maka tidak ada bagi pemilik modal selain modal pokok tersebut, begitu pula dengan pengusaha tidak mendapatkan apa-apa.Dan jika proyek rugi yang mengakibatkan hilangnya modal pokok maka kerugian itu sedikit ataupun banyak ditanggung oleh pemilik modal.Tidak diperkenankan kerugian itu ditanggung oleh pengusahanya dan menjadikannya sebagai jaminan bagi modalnya kecuali proyek itu didasarkan pada bentuk pinjaman dari pemilik modal kepada pengusaha. Jika demikian keuntungan pemilik modal tidak akan berkah. ${ }^{27}$

Berdasarkan definisi tersebut terdapat dua pihak dalam kontrak mudhârabah, yaitu pihak shahib al-maal dan mudhârib. Shahib al-maal adalah orang yang mempunyai surplus dana yang menyediakan dana tersebut untuk kepentingan usaha. Sementara mudhârib adalah pengelaola

27 Muhammad, Konstruksi Mudharabah Dalam Bisnis Syari'ah ( Yogyakarta: Pusat Studi Ekonomi Islam STIS Yogyakarta, 2003), h. 149 
Ujang Ruhyat Syamsoni :Problematika Penerapan Pembiayaan...

usaha yang membutuhkan dana dari shahib al-maal. Keduanya saiing memahami, artinya shahib al-maal mengenali mudhârib dan memahami jenis usaha yang akan dilakukannya, begitu pula mudhârib mengerti akan kemurahan hati shahib al-maal. Keduanya terlibat langsung dalam "kontrak "kerjasama yang saling membutuhkan tersebut dan dilakukannya sendiri secara sadar dan dapat memperkirakan hasil usahanya.

Sementara makna mudhârabah dalam sistem perekonomian modern, khususnya perbankan, menjadi berkembang. Pihak yang terlibat dalam kerjasama ini menjadi tiga; Pertama pihak yang menyimpan dana (depositor), Kedua pihak yang membutuhkan dana atau pengusaha (debitur) dan Ketiga pihak yang mempertemukan antara keduanya (bank) ${ }^{28}$ Pihak yang pertama, depositor, inilah seharusnya menjadi shahib al-maal sebab dia yang memiliki dana yang secara sadar akan digunakan untuk kepentingan usaha. Sedangkan pihak kedua (debitur) adalah mudhâribnya depositor, karena dia yang menggunakan dana depositir untuk digunakan sebagai modal usaha. Adapun pihak ketiga, bank, adalah pihak yang menjebantani keinginan keduanya (pihak pertama dan pihak kedua).Jadi fungsi bank ini menerima dan menyimpan dan shahib al-maal serta menyerahkan kepada mudhârib yang membutuhkan modal. Dengan kata lain jika shahib al-maal ingin mendayagunakan dananya harus melewati bank, begitu juga ketika mudhârib menghendaki dana untuk usahanya. Dalam kajian fiqh, perantara ini (samsarah) tidak dikenal dalam konteks kerjasama mudhârabah.

Namun dalam teori-teori ekonomi Islam yang dikembangkan oleh para intelektual dan praktisi perbankan syari'ah menyatakan bahwa dari ketiga pihak yang disebutkan di atas (depositor, debitur, dan bank) dalam sistem perbankan syari'ah memposisikan pihak bank sebagai pihak yang mempunyai standar ganda.Artinya, kerjasama mudhârabah dalam sistem berbankan syari'ah menempatkan bank sebagai mudharaaib sekaligus sebagai shahib al-maal.Sebagai mudhârib, bank mengelola dan yang dititipkan depositor untuk mencari keuntungan. Sementara shohib al-maal, bank memberikan dana para depositor kepada debitur untuk dikelola kepada sebuah usaha.

28Ibid., h. 29. 
Ujang Ruhyat Syamsoni :Problematika Penerapan Pembiayaan...

Posisi bank yang berstandar ganda tersebut tentu sedikit banyak membuat rancu pengertian mudhârabah yang dikembangkan ulama fiqh.Sebab antara shohib al-maal sebagai pemilik modal sesungguhnya dan mudhârib (entreneur) yang benar-benar mengerahkan tenaga dan keterampilan untuk sebuah usaha yang riil tidak bertemu secara langsung, tetapi harus melewati bank.Sementara bank sebagi lembaga usaha yang bergerak di bidang keuangan yang kegiatan operasionalnya harus didasarkan pada tingkat efisiensi, produktifitas dan profitabilitas yang layak mempunyai beberapa ketentuan-ketentuan khusus yang mengatur lalu lintas keuangan yang dilakukan oleh shohib al-maal dan mudhârib. ${ }^{29}$ Ketentuan tersebut tentu saja diatur sedemikian rupa sehingga proses intermediary berjalan tanpa hambatan dan dapat memberikan keuntungan khususnya bagi shahib al-maal dan bank itu sendiri.

Oleh karena itu penerapan mudhârabah pada sistem perbankan modern menjadi sangat rigit dan formal. Keadaan ini tentu harus disadari karena mudhârabah yang sesungguhnya merupakan sistem kerjasama masyarakat yang hidup jauh sebelum munculnya Islam dan mengalami kejayaan pada masyarakat yang hidup pada abad pertengahan di masa tingkat kesederhanaan sarana dan prasarana dilakukan dengan sistem kepercayaan (nonformal), ${ }^{30}$ sekarang dipaksa untuk beradaptasi dengan iklim perekonomian modern. Oleh karena itu aplikasinya dalam aktifitasaktifitas keuangan modern dalam masyarakat industri dan kompleks tersebut tidak dapat memberikan validitas bagi pemberlakuannya. ${ }^{31}$

Pemberlakuan mudhârabah dan beberapa teori ekonomi lainnya yang termuat dalam literatur fiqh, dalam sistem perekonomian modern sebagai fenomena munculnya gerakan formalisas dan kontrainnisasi dalam usaha membangkitkan kembali teori-teori tersebut tanpa menyadari perubahan waktu dan tempat yang seharusnya diikuti.Namun demikian betapapun mudhârabah sekarang ini dipraktekkan secara kurang tepat tidak berarti

\footnotetext{
${ }^{29}$ Faisal Arif, Strategi dan Operasional Bank (Bandung: Eresco, 1996), h. 6.

${ }^{30}$ Gemala Dewi, Aspek-aspek Hukum dalam Perbankan dan Perasuransian Syari'ah di Indonesia (Jakarta: Kencana Prenada Media Group, 2007), h. 16

${ }^{31}$ Sutan Remy Sjahdaini, Perbankan Islam dan Kedudukannya Dalam Tata Hukum Perbankan Indonesia (Jakarta: Imtaka Utama Grafiti, 2005), h.19
} 
Ujang Ruhyat Syamsoni :Problematika Penerapan Pembiayaan...

mudhârabah tidak dapat masuk dalam lingkungan bisnis modern. Memposisikan mudhârabah dalam sistem perekonomian modern berpijak pada teori-teori fiqh dan landasan filosofinya secara konsisten dan mandiri, tidak mengikuti yang lain agar lerhindar dari kesar penjiplakan sistem yang merubah kemasan tanpa mengganti ini.

Dalam hal ini mudhârabah bisa dibangun melalui lembaga Baitul maal yang mempunyai rujukan historis yang jelas dan menjadi lembaga pemerintah yang mengurusi masalah sosial dan perekonomian masyarakat Islam saat itu.Aplikasi dalam iklim modern ini tentu tidak hanya mengurusi masalah zakat, infaq dan shadaqah tetapi juga disesuaikan dengan kondisinya.Baitul Maal mengkondisikan dirinya menjadi sebuah lembaga biro jasa yang menjembatani transaksi-transaksi perekonomian yang dilakukan oleh masyarakat.Dalam perannya sebagai biro perantara ini fungsi utama Baitul Maal hanya mempertemukan para pemilik modal atau barang dengan mudhârib dalam transaksi mudhârabah dan transaksi-transaksi Iainnya.Sebagai perantara Baitul Maal tidak terlibat secara teknis atas segala ketentuan yang harus disepakati oleh kedua pihak tersebut.

c. Problem Kejujuran (al-shidq atau al-Amin)

Dalam syari'at Islam terkandung norma-norma yang harus ditaati oleh manusia sebagai penerima taklif.Norma-norma tersebut menjadi undangundang yang mengatur kehidupan manusia dalam rangka menciptakan kehidupan yang tenang dan tenteram. Satu norma universal yang sangat penting dalam kaitannya dengan interaksi sosial adalah al-shidq. Kejujuran atau al-amin, orang yang dapat dipercaya.

Dalam fiqh muamalat kata al-amin lebih banyak digunakan dari pada al-shidq.Karena kata tersebut dikaitkan dengan kata al-amanah, suatu titipan yang harus dijaga mu'taman atau amin, orang dipercaya untuk menjaga amanah. Dalam penjelasannya yang lebih detail, amanah merupakan pesan atau titipan dari seseorang yang harus dijaga keselamatannya oleh mu'taman (amin) tidak untuk diingkarinya, dan jika mu'taman (amin) mengingkarinya maka ia harus mengganti terhadap setiap kerugian atau kerusakan yang terjadi. 
Ujang Ruhyat Syamsoni :Problematika Penerapan Pembiayaan...

Di samping kata ini terdapat kata al-wakil yang menjadi kata kunci bagi mudhârib dalam menjalankan usahanya.Al-wakil adalah orang yang dipercaya oleh orang lain sebagai agen darinya dalam melaksanakan tugas atau kegiatan. Dalam wacana fiqh muamalat istilah wakil berkaitan erat dengan pembahasan masalah wakalah, kerjasama mencari keuntungan antara dua pihak yang menjadikan satu pihak sebagai muwakil yang mengurus atau menjadikan mandat sebuah usaha dan pihak lain sebagai wakil. Utusan yang dipercaya untuk mengemban tugas usaha muwakkil.320leh karena itu apapun yang terjadi dalam kerjasama wakalah ini menjadi tanggung jawab muwakkil, sementara wakil tidak mempunyai kewenangan apapun karena dia diupah secara tetap oleh muwakkil.

Dalam teori yang dikembangkan para pemikir dan praktisi perbankan syari'ah kedua kata ini, amin dan wakil (sistem amanah dan wakalah) dijadikan sebagai sebutan bagi mudhârib dalam kontrak mudhârabah.Kata amin diinisialkan kepada mudhârib dengan maksud agar mudhârib benarbenar menjaga titipan (modal) yang diberikan shahib al-maal kepadanya dijaga dan dirawat secara hati-hati serta dipergunakan sebagaimana mestinya agar tidak menimbulkan kerusakan atau kerugian.Namun perbedaan makna amin dalam amanah dan amin dalam mudhârabah sebagai inisial dari mudhârib terdapat dalam penggantian kerugian.Dalam maknanya yang sebenarnya, kerugian harus ditanggung oleh amin, sedangkan dalam mudhârabah kerugian dipikul oleh shohib al-maal atau orang yang menitipkan barang.

Begitu pula dalam wakil penyiasatan seperti ini muncul ketika dalam kerugian mudhârib tidak akan mendapatkan apa-apa sementara wakil tetap mendapatkan laba sebagai remuneration tetapnya.Namun penyiasatan itu muncul pada konteka wakalahnya atau sistem perwakilannya di mana shohib al-maal mempunyai kewenangan apapun dalam mengatur wakilnya. Sementara mudhârib sebagai wakil tidak akan berbuat bebas karena dia hanyalah seorang agen, tangan kedua dari shahib al-maal. h.399.

32 Ibnu Abidin, Radd al-Muchtar ala al-Durr al-Mukhtar, (Beirut: Dar Ihya al-Turats, 1987, Juz IV, 
Ujang Ruhyat Syamsoni :Problematika Penerapan Pembiayaan...

Pemberian sebutan bagi mudhârib dalam kontrak mudhârabah dengan amin ataupun wakil dengan ambigu sebab kedua istilah tersebut mempunyai implikasi teknis yang berbeda.Tentu saja tidak bisa dipersamakan dengan mudhârib dalam kontrak mudhârabah.Kesan yang mudah di tangkap dalam kaitannya dengan penyebutan itu adalah adanya tindakan antisipatif shohib al-maal (bank syari'ah) sekaligus penggiringan mudhârib dalam sebuah ruang yang dirancang agar mudhârib tidak dapat berbuat apapun jika pada suatu saat terjadi kerugian dalam kontrak mudhârabah.

Masalah amin atau wakil seharusnya ditempatkan pada proporsinya yang tepat.Penyiasatan kedua istilah tersebut untuk kepentingan pengukuhan keberadaan sistem mudhârabah dalam perbankan syari'ah merupakan tindakan yang mengadangada. Perlu kiranya dimunculkan pemahaman yang benar akan hakekat mudhârabah. Mudhârabah memang sebuah kerjasama yang membutuhkan kejujuran total dari kedua pihak terlebih bagi mudhârib. Kejujuran yang dimaksud meliputi hal-hal yang berkaitan dengan pengelolaan usaha dan pelaporan hasil usahanya. ${ }^{33}$

2. Aspek Internal

a. Mekanisme Pembagian Bagi Hasil

Sebagai ukuran untuk menentukan dan mengetahui tingkat kesiapan masyarakat dalam menggunakan mudhârabah dapat digambarkan dengan contoh sebagai berikut:

Seorang pekerja ingin meminjam uang kepada pemilik modal atau bank sebesar Rp. 7 juta untuk mendirikan usaha cuci sepeda motor, uang tersebut digunakan untuk keperluan, mesin penyedot air (sanyo) 4 juta, seperangkat peralatan cuci motor Rp.l juta, Tempat/kios Rp.1,5 juta dan sisanya Rp.500 untuk jual beli bensin eceran.

Dalam menghadapi keinginan mudhârib, biasanya shohib al-maal ada dua pilihan dalam menyepakati model transaksi; melalui profit and Loss Sharing atau Revenue Sharing. Profit and Loss Sharing diidentikan dengan

${ }^{33}$ Moedigdo Sigit Prakoso, Permasalahan Penerapan Mudharabah di Bank Syari'ah, makalah disampaikan pada diskusi rutin Forum Pemberdayaan Lembaga Keuangan Syari'ah Yogyakarta, h. 3. 
Ujang Ruhyat Syamsoni :Problematika Penerapan Pembiayaan...

mudhârabah sedangkan Revenue Sharing merupakan kebalikannya, membebankan keuntungan ataupun kerugian kepada mudhârib. ${ }^{34}$

Dengan menggunakan sistem PLS, shohib al-maal akan membiayai semua kebutuhan tersebut dengan mensepakati pembagian hasil pada prosentase tertentu dan merealisasikan pembagiannya pada akhir masa kontrak. Pengangsuran model pinjaman dilakukan setiap bulan jika diasumsikan masa usaha (pinjaman) yang disepakati selama 6 bulan, maka perhitungan pengangsurannya Rp. 7 juta : 6 bulan = Rp. $1.167 .000 /$ bulan. Jadi angsuran yang harus dibayar oleh mudhârib tiap bulannya adalah Rp. 1.167.000 ditambah biaya administrasi. Kemudian jika diasumsikan kesepakatan bagi hasil dengan proporsi $60 \%$ untuk mudhârib dan $40 \%$ untuk bank dan laba yang diperoleh pada akhir kontrak Rp. 5 juta, maka perhitungan keuntungan yang didapat oleh mudhârib adalah (60:100) x 5 juta = Rp. 3 juta. Sisa dari jumlah itu sebesar Rp. 2 juta menjadi keuntungan shahib al-maal.Jadi keuntungan yang diperoleh bank syari'ah pada masa 6 bulan adalah Rp. 3 juta ditambah biaya administrasi.

Sementara jika shahib al-maal menggunakan sistem Rrevenue Sharing, maka ia hanya akan menetapkan angsuran yang sama dengan PLS yaitu 1.167.000 / bulan ditambah bunga sebesar $24 \%$ pertahun untuk biaya administrasi dan operasional bank, sehingga jumlah angsuran tiap bulannya adalah sebesar Rp. 1.1450.000 / bulan. Kalau dihitung laba bank selama masa kontrak 1.450 .000 × $6=$ Rp.8.700.000 -7.000 .000 (uang pokok) $=$ Rp. 1.700.000.

Dari dua mekanisme transaksi di atas, secara umum orang akan berpikir dua kali jika ingin menggunakan sistem mudhârabah (PLS) dengan alasan sebagai berikut:

1. Biaya administrasi pada sistem PLS sama dengan bunga, karena bungapun pada prinsip untuk membiayai kegiatan administrasi dan operasional shahib al-maal (Bank).

${ }^{34}$ Muhammad, Sistem dan Prosedur Operasional Bank Syariah, (Yogyakarta: UII Press, 2005), cet. 
Ujang Ruhyat Syamsoni :Problematika Penerapan Pembiayaan...

2. Pada akhir masa kontrak, sistem RS tidak lagi memungut biaya apapun, sementara dalam PLS hasil atau keuntungan yang diperoleh mudhârib harus dibagi oleh dua pihak.

3. Sistem PLS tidak praktis karena menuntut adanya kehati-hatian dari mudhârib dan dituntut untuk selalu membuat catatan neraca laba-rugi pada setiap bulannya. Seadangkan pada sistem RS sangat praktis, efektif dan efisien.

4. Jika dilihat dari perolehan keuntungan mudhârib, maka yang paling banyak memberikan keuntungan adalah sistem RS (RevenueSharing), sebab keuntungan sebanyak 5 juta tersebut akan menjadi milik mudhârib sepenuhnya. Sedangkan dalam PLS, mudhâribakan mendapatkan sedikit keuntungan sebab disamping adanya pemungutan biaya administrasi juga adanya pembagian hasil kerja mudhârib.

Bentuk sesuai dengan pola pemikiran masyarakat modern sekarang ini tentulah system RS (Revenue Sharing), sebab disamping praktis efektif dsan efesien juga kebebasan individual dalam berusaha tidak menuntut jaminan atas kejujuran yang dikehendaki oleh bank.Apalagi legitimasi mudhârabah sebagai sistem yang syar'i membuat nasabah (mudhârib) tidak berani menjamin kejujurannya untuk hal-hal sepele yang kadang-kadang dilakukan secara tidak sadar. Kecenderungan atas pilihan ini akan semakin kuat jika pada tataran realistis praktek sistem PLS atau mudhârabah pada perbankan syari'ah tidak jauh berbeda dengan sistem RS (konvensional), sebagaimana yang terjadi pada praktik-praktik perbankan syari'ah sekarang ini.

b. Permasalahan Garansi (Jaminan)

Dasar yang menjadi acuan bagi pembolehan garansi, biasanya para pemikir dan praktisi perbankan syari'ah merujuk pada surat al- Baqarah ayat 282 dan ayat 283. Mereka menafsirkan perintah pencatatan oleh para penulis dan pengadaan para saksi sebagai bentuk lain dari garansi dengan tujuan menciptakan kontrak muamalah tersebut menjadi serius dan mempunyai implikasi hukum yang mengikat kedua pihak. Penetapan garansi dalam mudhârabah pun, menurut mereka seperti itu, Namun yang kurang dapat dipahami adalah mempermasamakan antara kegiatan hutang pihutang dengan kontrak mudhârabah (kerjasama bagi hasil).Dalam kontrak hutang 
Ujang Ruhyat Syamsoni :Problematika Penerapan Pembiayaan...

pihutang para ulama fiqh pun sepakat memperbolehkan adanya jaminan, tetapi dalam kontrak mudhârabah mereka sepakat meniadakannya.

Di samping itu praktek transaksi mudhârabah dalam perbankan syari'ah dengan melalui beberpa prosedur baik administrasi ataupun melalui ketentuan umum dan khusus merupakan jaminan bagi keseriusan mudhârabah dalam menjalankan usaha, maka dari itu tidak perlu lagi dipersyaratkan adanya jaminan. Karena hal itu akan mengkondisikan jalannya kontrak mudhârabah menjadi tidak sehat.

Penerapan jaminan pada perbankan syari'ah mutlak tak dapat dihindari.Berdirinya bank syari'ah sebagai lembaga usaha mengakibatkan tingginya tingkat kekhawatiran dari pada berdiri sebagai lembaga sosial. Di Indonesia, misalnya, besamya nilai jaminan mengakibatkan permasalahan tersendiri. Bagi pengusaha pengusaha kecil apa mungkin mempunyai uang jaminan sebesar itu. Jika ia mempunyai uang jaminan sebesar itu buat apa mereka meminjam pada bank. Memang jaminan tidak selalu uang tunai, tetapi barang yang harganya sebesar itu tentu merupakan harta yang paling penting dan berharga yang dimiliki pengusaha.

Oleh karena itu mereka tidak mau mempertaruhkannya. Sebaliknya dengan besarnya uang jaminan akan menjadi hal yang biasa bagi para pengusaha kaya. Mereka dengan kelebihan hartanya akan mudah meminjam modal dari bank untuk pengembangan usahanya.

Keadaan seperti ini menunjukkan bahwa penerapan jaminan di perbankan syari'ah semakin membuka akses bagi para pengusaha kaya untuk mengembangkan lebar-lebar sayap perusahaannya dan pada akhirnya muncul ketimpangan-ketimpangan sosio-ekonomi yang lebih tajam di da'am masyarakat.Implikasi seperti ini tentu sangat berlawanan dengan misi sebenarnya yang diemban perbankan syari'ah.

Untuk mengantisipasi keadaan seperti ini, perlu kiranya dipertimbangkan kembali tentang problem garansi ini. Jika perbankan syari'ah ingin menerapkan sistem perbankan yang islami tentu jaminan harus ditiadakan, namun jika jaminan terpaksa diberlakukan dengan alasan takut terjadinya ketidak-jujuran atau wanprestasi dari para nasabahnya, maka perlu menetapkan pemberlakuannya melalui kriteria besar kecilnya 
Ujang Ruhyat Syamsoni :Problematika Penerapan Pembiayaan...

modal yang dipinjam atau dapat dipantau atau tidaknya usaha yang dilakukan oleh mudhârib. Oleh karena itu observasi sebagai bahan pengklarifikasian usaha tersebut perlu dilakukan sebelum persetujuan kerjasama ditetapkan.

c. Penetapan Masa Kontrak

Mengamati beberapa perbedaan pendapat diantara madzhab fiqh dapat disimpulkan bahwa kontrak mudhârabah pada hakekatnya tidak memerlukan pembatasan waktu.Namun dalam perbankan syari'ah sebagai lembaga usaha yang mengurusi peredaran uang simpanan yang dipinjamkan kepada mudhârib tentu membutuhkan kejelasan lamanya waktu yang dibutuhkan mudhârib. Kejelasan tentang hal itu menjadi kebutuhan bank dalam memproyeksi keuntungan yang akan didapatnya dan merencanakan program-program lain yang dapat dijadikan sebagai sumber dana (keuntungan). Semakin jelas proyeksi laba semakin jelas pula proporsi bagi hasil antara bank dengan depositonya.

Mengingat bahwa kejelasan masalah waktu menjadi bagian yang urgen dalam perbankan syari'ah, maka untuk kesekian kalinya teori fiqh mudhârabah diadaptasikan dengan sistem yang ada.Penyelesaian ini diaplikasikan dengan menyediakan pilihan-pilihan jangka waktu yang sudah ditetapkan bank sebelumnya kepada mudhârib.Misalnya, untuk investasi jangka pendek disediakan satu bulan, tiga bulan, enam bulan, satu tahun, atau diatas satu tahun termasuk dalam investasi jangka panjang.Kesepakatan masalah jangka waktu investasi ini tidak dimusyawarahkan sebelumnya antara kedua pihak, tetapi mudhârib disuruh memilih jangka waktu yang sudah ditentukan oleh bank.Pendek kata pemilihan jangka waktu yang selain ditawarkan tidak dapat diterima oleh bank.

Di samping penentuan jangka waktu yang ditetapkan bank, pada kenyataannya perbankan syari'ah mensepakati pilihan jangka waktu mudhârib tersebut berdasarkan kriteria khusus, tingkat kekhawatiran bank terhadap karakter dan kredibilitas mudhârib. Bagi para peminjam (pengusaha) pemula akan mendapat pilihan jangka waktu yang pendek 
Ujang Ruhyat Syamsoni :Problematika Penerapan Pembiayaan...

antara satu bulan hingga tiga bulan, karena karakter dan kredibilitas mudhârib masih dalam status diragukan.

Sedangkan bagian mudhârib yang karakter dan kredibilitasnya diakui diperbolehkan mengambil masa investasi antara enam sampai 12 bulan. Dan untuk mudhârib yang statusnya dijamin, akan mendapatkan kelonggaran jangka waktu yang lebih panjang. Dari sini sangat sulit bagi perbankan syari'ah untuk menetapkan teori fiqh mudhârabah secara murni.Jangka waktu yang pada awalnya diberikan kepada mudhârib secara bebas dengan alasan mudhârib dapat merencanakan dan merancang langkah-langkah usahanya secara tepat dan menghasiikan keuntungan yang optimal menjadi tidak berdaya dengan adanya batasan-batasan waktu.

\section{E. Kesimpulan}

Problem yang dihadapi oleh Bank BRI Syari'ah Kuamang Kuning dalam mengaplikasikan akad mudhârabah adalah dijumpainya pergeseran-pergeseran seperti penentuan bagi hasil yang tidak bergantung pada kesulitan dan kebutuhan mudhâribtetapi kredibilitas, kecakapan bargaining, prospektifitas usaha, tingkat laba aktual, tingkat bunga serta pengambilan masa kontrak.Pengaturan usaha tidak mendudukkan mudhârib sebagai pemilik otoritas penuh, intervensi bank membuatnya terbatas dalam mengambil langkah dan keputusan.Garansi merupakan pengikat atas pertaruhan usaha laba rugi mudhârib yang tidak mungkin terhindarkan. Penyelesaian akad mudhârabah dalam sistem perbankan syari'ah ditentukan dalam akad yang dipersiapkan oleh bank syari'ah dengan klasula secara rinci dan detil sehingga bank syari'ah bisa menghindar dari resiko jika terjadi wanprestasi yang dilakukan oleh pihak mudhârib (pelaksana usaha) atau jika terjadi klaim dari shobil al-maal (investor).

\section{Daftar Pustaka}

Kementerian Agama RI, Alqur'an dan Terjemahnya, Bandung: Syamil Qur'an, 2012.

Abaraham L.Udovitch, Partnership abd Profit in Medival Islam, New Jersey: Princeton University Press, 1970.

Adiwarman Karim, Bank Islam analisis Fiqh dan Keuangan, Jakarta: Raja grafindo Persada, 2004.

Al-Kasanai, Bada'i' al-Shana'i' fi Tartibi al-Syara 'i', Beirut: Dar el-Kutub, t.th.

Faisal Arif, Strategi dan Operasional Bank, Bandung: Eresco, 1996. 
Ujang Ruhyat Syamsoni :Problematika Penerapan Pembiayaan...

Gemala Dewi, Aspek-aspek Hukum dalam Perbankan dan Perasuransian Syari'ah di Indonesia, Jakarta: Kencana Prenada Media Group, 2007.

Hendi Suhendi, Fiqh Muamalah, Jakarta: Raja Grafindo Persada, 2013.

Herry Sutanto dan Khaerul Umam, Manajemen Pemasaran Bank Syari'ah, Bandung: Pustaka Setia, 2013.

Ibnu Abidin, Radd al-Muchtar ala al-Durr al-Muchtar, Beirut: Dar Ihya al-Turats, 1987. Muhammad, Sistem dan Prosedur Operasional Bank Syariah, Yogyakarta: UII Press, 2005.

Jaih Mubarok, Perkembangan Fatwa Ekonomi Syari'ah di Indonesia, Bandung: Pustaka Bani Quraisy, 2004.

Kasmir, Manajemen Perbankan, Jakarta: Raja Grafindo Persada, 2015.

Muhamamd Syafi'i Antonio, Bank Syariah dari Teori ke Praktik, Jakarta Gema Insani Press, 2002.

Muhammad Ridwan, Kontruksi Bank Syariah Indonesia, Yogyakarta: Pustaka SM, 2007.

Muhammad, Konstruksi Mudharabah Dalam Bisnis Syari'ah, Yogyakarta: Pusat Studi Ekonomi Islam STIS Yogyakarta, 2003.

Neneng Nurhasanah,Mudharabah dalam Teori dan Praktik, Bandung: Refika Aditama, 2015.

Otoritas Jasa Keuangan (OJK), Statistik Perbankan Syari'ah 2016, Jakarta: OJK, 2020.

Shalah ash-Shawi dan Abdullah al-Muslih, Fikih Ekonomi Islam, Jakarta: Darul Haq, 2013.

Sutan Remy Sjahdaini, Perbankan Islam dan Kedudukannya Dalam Tata Hukum Perbankan Indonesia, Jakarta: Imtaka Utama Grafiti, 2005.

Wiroso, Produk Perbankan Syari'ah, Jakarta: LPFE, 2009. 